\title{
Between the Poetic and the Documentary: Ukrainian Cinema's Responses to World War II*
}

\author{
Vitaly Chernetsky \\ University of Kansas
}

While the "ethnic" cinematic traditions of the Soviet Union are receiving increasing recognition in recent years, they remain little studied and little appreciated as examples of World War II-centered films, even though one such non-Russian Soviet republic, Ukraine, provided a key locus both in the establishment of the genre of World War II documentary (in the work of Alexander Dovzhenko) and in the making of the paradigm of guerrilla fighter ("partisan") films with Mark Donskoi's The Rainbow (1943, rel. 1944). ${ }^{1}$ The latter film established the presentation of Nazi-occupied Soviet territory through the fate of women characters that became a paradigmatic feature of a large number of both films and literary works. It also gave us the classic images of the noble suffering maternal female character (Natalia Uzhvii's Olena), the immoral hedonist collaborator (Nina Alisova's Pusia), and the selfless partisan fighter (Ol'ha, Pusia's sister, played by Vera Ivashova, best known for her role as Ol'ga Danilovna, the Novgorod beauty in Eisenstein's Alexander Nevsky).

It is Dovzhenko's films, however, that inaugurated a Ukrainian response to the events of the war. With his trilogy of wartime documentary films, for all the genre and content limitations of official Soviet wartime chronicle, he built narrative and visual bridges to the first golden age of Ukrainian cinema during the VUFKU years,

\footnotetext{
*I would like to thank Dr. Sander Brouwer, the organizer of the conference from which this volume has resulted, as well as the fellow conference participants, for the helpful feedback.

${ }^{1}$ With the exception of Donskoi's Rainbow, a widely acknowledged classic, no Ukrainian World War II films are even mentioned in such influential and important studies as Woll 2000 or Youngblood 2007.
} 
marked by his canonical silent film trilogy (Zvenyhora, Arsenal, Earth) and Dziga Vertov's idiosyncratic, innovative work produced at VUFKU, most notably his masterpiece Man with a Movie Camera. Buoyed by the relative relaxation of censorship and by the successes of Soviet troops recapturing Ukraine, Dovzhenko developed an idea for a more personal, deeply felt film to be titled Ukraine in Flames. Yet, tragically, the film script was singled out for attack by the Politburo and by Stalin personally at the Politburo meeting held on 30 January 1944. With the speech ominously titled "On the Anti-Leninist Errors and Nationalist Perversions in Dovzhenko's Film Script Ukraine in Flames" ("Ob antileninskikh oshibkakh i natsionalisticheskikh izvrashcheniiakh $\mathrm{v}$ kinopovesti Dovzhenko 'Ukraina v ogne'") Stalin effectively brought Dovzhenko's cinematic career to a halt. Dovzhenko himself, recalling this event a year later, called it his death, when he "was chopped to pieces and the bloodied fragments of my soul were scattered around for shame and reproach at every meeting.",2 The project Dovzhenko hoped to undertake, I would argue, was to be a unique combination of his signature aesthetic of poetic cinema, on the one hand, and of the idiosyncratic documentary aesthetic drawing on the ideas of Vertov and other pioneers of innovative documentary filmmaking, an experimental poetic cinema hybrid of the diary and the essay which would have resulted in what film scholars are increasingly calling "essay film."

This concept, used with increasing frequency in contemporary film studies, remains relatively undertheorized, even if its first discussions can be traced back to Eisenstein's writings on his October and the unrealized Das Kapital project. It is commonly viewed as "a hybrid form, which crossed boundaries and rests somewhere in between fiction and nonfiction cinema" (Rascaroli 2009: 21). A number of scholars, such as Timothy Corrigan, consider the essay film as part of a larger concept of the essayistic spanning across genres and artforms:

Appearing within many different artistic and material forms besides the essay film, the essayistic acts out a performative presentation of self as a kind of self-negation in which the narrative or experimental structures are subsumed within the process of thinking through a public experience. In this larger sense, the essay film becomes most important in pinpointing a practice that

\footnotetext{
${ }^{2}$ Dovzhenko, diary entry, 31 January 1945, quoted in Oleksandr Dovzhenko: Tvorcha spadshchyna: 51 .
} 
renegotiates assumptions about documentary objectivity, narrative epistemology, and authorial expressivity within the determining context of the unstable heterogeneity of time and place. (Corrigan 2011: 6)

Nora M. Alter, who has written on essay film extensively in the context of the German film tradition, views it as "not a genre, as it strives to go beyond formal, conceptual, and social constraint. Like 'heresy' in the Adornean literary essay, the essay film disrespects traditional boundaries, is transgressive both structurally and conceptually, it is self-reflective and self-reflexive" (Alter 1996: 171) In a later study, Alter adds that "[u]nlike the [traditional] documentary film, which presents facts and information, the essay film produces complex thought that at times is not grounded in reality but can be contradictory, irrational, and fantastic" (Alter 2002: 7).

In her 2009 book The Personal Camera: Subjective Cinema and the Essay Film, Laura Rascaroli offers the most comprehensive investigation of this filmic form to date across national cinematic traditions, and across the sub-genres of the diary film, the travelogue film, the "notebook film," and the cinematic self-portrait, taking her analysis from Chris Marker and Godard to, crucially, Pasolini and Sokurov. By highlighting the latter two directors in particular, she links the essay film phenomenon with the key instances of the poetic cinema tradition. Film as poetry encounters and joins film as essay in a hybrid form. "Essayistic cinema," Rascaroli emphatically asserts, "is irreducibly plural" (Rascaroli 2009: 189).

The concept of the essay film heretofore has not yet been extensively used in discussions of the Ukrainian cinematic tradition; by contrast, Ukrainian cinema's linkage to another theoretical concept, namely poetic cinema, has dominated the scholarly narrative. However, looking at theorizations of poetic cinema and Ukrainian poetic cinema in particular, one discovers striking parallels. Thus Bruce Williams, in his seminal article "A Mirror of the Cinema: Poetic Discourse and Autotelic Aesthetics in Dovzhenko's Earth," highlights several aspects crucial to this type of filmmaking. First and foremost, "formal mechanisms ... render the film's rudimentary story virtually insignificant, particularly in comparison with the strength of the visual imagery"; drawing on Pasolini, Williams and others highlight poetic cinema's preoccupation with dreams and fragmented

\footnotetext{
${ }^{3}$ Emphasis in the original.
} 
memories: the world presented to the viewer has undeniable dreamlike qualities, with "purity of images transcending the point of view to which they are diegetically linked." Seconding Shklovsky, Williams also emphasizes that poetic cinema privileges the compositional aspect over the semantics of narrative progress (Williams 1994: 67, 69, 72). Elizabeth Papazian, in her analysis of Dovzhenko, identifies the key device of his brand of poetic cinema as follows:

\footnotetext{
Dovzhenko uses offscreen space, along with a related technique of 'unreported speech,' to allude to a utopian vision; the presence of the utopian impulse is also revealed in a striving toward visual and thematic synthesis. The nature of this utopia and its relation to the Soviet project, however, is rendered ambiguous and must be resolved by the viewer" (Papazian 2003: 412).
}

There is, I would argue, a potential for a profound affinity between the subjective yet pluralistic exploratory projects of essay film on the one hand and poetic cinema's creation of ambiguous visual utopias that eschew narrative transparency on the other.

As is well known, however, in the context of the struggle for survival during worsening Stalinist repression, Dovzhenko's completed films from the mid-1930s onwards, beginning with Aerograd (1935), are but a pale shadow of his earlier innovative work. The completed wartime documentaries, sadly, are no exception. However, the short-lived relaxation of censorship during the war years emboldened some of the "captive generals" of Ukrainian literature in the Soviet Union to depart from the strictures of socialist realism, notably in the narrative poem "Pokhoron druha" ("The Funeral of a Friend," 1942) by Pavlo Tychyna, a giant of Ukrainian modernist poetry in the 1910s - early 1920s. Dovzhenko's boldly experimental yet unrealized Ukraine in Flames, part of the same aborted revival, thus forms a bridge from his earlier canonical poetic films to the next rise of innovative Ukrainian cinema in the 1960s.

Significantly, this rise coincided with the return of World War II to a central position in Soviet cultural discourse. As Denise Youngblood notes, during the first decade after World War II, "war as national tragedy remained virgin territory for directors" in the USSR (Youngblood 117), only to move center stage with a series of outstanding films beginning with Kalatozov's Letiat zhuravli (Cranes Are Flying) in 1957 and ending with Tarkovsky's Ivanovo detstvo (Ivan's Childhood, a.k.a. My Name Is Ivan) in 1962. Ukrainian 
cinema of the late 1950s - early 1960s, alas, can hardly be considered part of this trend. Even what one may consider the highlight of the period, Viktor Ivchenko's Ivanna, watched by more than 30 million viewers when it was released in 1960, is little seen and discussed these days. Still, Ivanna is a film that simultaneously probes a new ground by portraying for Soviet audiences an aspect of the conflict that was rarely discussed in Soviet film before: the role of organized religion (here specifically the Greek Catholic Church, banned in postwar Soviet Union), and reinterprets a tragic young heroine who sacrifices herself for the cause of liberty, familiar from such classic World War II films as Leo Arnshtam's Zoia (1944). The film is named after the protagonist, daughter of a Greek Catholic priest, honest and naïve; in 1940, during the first Soviet takeover of Western Ukraine, following her father's blessing she becomes engaged to a young seminary student, Roman, who is a member of the underground anti-Soviet Ukrainian nationalist movement. $\mathrm{He}$ is about to be arrested by the NKVD when the Nazi invasion prevents this. Meanwhile, Ivanna, posing as a nun, organizes an escape of a group of POWs, most of them Ukrainian, from a Nazi camp; however, her fiancé denounces her to the occupying authorities, and she is tortured and killed by the Nazis. In the process, she comes to renounce her religion. In its presentation of its setting, Ivanna, as one may expect, is much closer to contemporaneous Polish films, especially Andrzej Wajda's war trilogy (Pokolenie [A Generation], Kanat, Popiót $i$ diament [Ashes and Diamonds]). In terms of its presentation of the main characters, however, the film stays firmly within Soviet norms, giving us in the case of Ivanna an instance of an innocent but inherently good melodramatic heroine who succeeds in "raising her consciousness" and accomplishing a daring and courageous act of anti-Nazi resistance, and in Roman a stereotypical duplicitous "bourgeois nationalist."

The world of Ukrainian cinema radically changed, however, with the release of Paradzhanov's Tini zabutykh predkiv (Shadows of Forgotten Ancestors) in 1965. This radically innovative film, preoccupied, as it happens, with traces of another locus of memory that became a major focus for Ukrainian filmmakers, namely the traditional Hutsul culture in the Carpathians, exercised a radical paradigm shift in Ukrainian cinema, enabling a series of daring, innovative works to emerge in the few years before the destruction of 
the poetic cinema school in 1973. While, tragically, it remained Paradzhanov's last completed film project in Ukraine, in what has survived of his next, aborted project, Kÿ̈vs'ki fresky (Kyiv Frescoes) - in the script and in the surviving 15 minutes of footage for the film-memory of World War II occupies center stage.

Conceived in the context of solidification of the new official Soviet war narrative, the plot of the film pivots around the symbolic date of May 9, 1965, bringing together the characters named simply as "Man," a film director, "Woman," a war widow and a museum custodian, and "Longshoreman" (Gruzchik), along with a host of episodic figures in a kaleidoscope of impressions of contemporary life in Kyiv. A crucial scene was to present a group of soldiers tiptoeing past the Woman to admire the beauty of paintings in the museum where she works, the Khanenko Museum of Arts in Kyiv (then known as the Museum of Western and Oriental Art), home of a famed portrait of the Infanta Margarita by Diego Velázquez which figures crucially in Paradjanov's script. As James Steffen has argued, "This selfreflexive, autobiographical aspect of the script, which incorporates dreams and the fantastic, is undoubtedly inspired by Fellini's $81 / 2$, which was widely seen and discussed among filmmakers and critics in the Soviet Union at that time and was among Paradjanov's favorite films" (Steffen). In his interpretation of the film, Steffen argues that

\begin{abstract}
Paradjanov's vision in the script is profoundly humanistic; through close observation of the characters' individual gestures, not only does he affirm the basic generosity and kindness of people on an everyday level, but he celebrates art as a reflection of their inner beauty and their capacity for good. While he acknowledges the sacrifices that war entailed, for him war is not the natural state of human existence ...While humans still possess the capacity for violence, Paradjanov views it as an immature state (idem).
\end{abstract}

I would argue that the film Paradjanov conceived, with its strong selfreflexive bent, was meant to be a quintessential essay film, operating, as we can see, with all the signature devices of his poetic cinema style. While it remained unfinished, the remaining years of the heyday of Ukrainian poetic cinema brought us two key films that, although operating within the generic confines of fiction film, pursued, to a significant degree, the essayistic/poetic hybridization.

While Paradjanov's hybrid film project did not see completion, within a few years several other Ukrainian films, following in his footsteps, provided ambitious hybrid forms of their own, blending 
elements of poetic cinema and, at times, of the essayistic approach, with the safer tenets of socialist realism. These compromise, although not compromised, projects are thus aesthetically akin to Dovzhenko's first sound venture, Ivan (1932), where he fights to preserve vestiges of his original vision against pressures of ideological and aesthetic conformity. Two of these films considered below are anchored more strongly on the narrative fiction film side, while containing, much like such Western works of poetic cinema as Terrence Malick's The Thin Red Line, elements of the essayistic. ${ }^{4}$ The third, although not as well known than the other two, offers arguably the most ambitious example of a completed project of an essay film proper within the Ukrainian poetic cinema tradition.

While the 1971 feature Bilyi ptakh z chornoiu oznakoiu (White Bird with a Black Mark, dir. Yuri Illienko), a poetic cinema classic focused on the fates of male characters (three brothers) from 1937 to 1947, became arguably the best known Ukrainian film set during World War II made during the post-Stalin era, it was predated by two feature-length debuts: the 1968 film Annychka, the debut feature by one of the prominent members of the Ukrainian poetic cinema school, Borys Ivchenko (1941-1990), based on a script co-authored by his earlier mentioned father Viktor Ivchenko (1912-1972), a prominent director in his own right, if a much more cautious and conservative one than his son, and the 1967 film Khto povernet 'sia-doliubyt' (The Returnees Shall Complete the Task of Love), the reworking by Leonid Osyka (1940-2001) of an aborted project begun by another director, Vasyl' Illiashenko (b. 1935). In the pages below, I will first consider Annychka and Bilyi ptakh, moving next to Osyka's film.

The nine years that separate the filming of Ivanna, the bestknown war-themed film directed by Ivchenko Sr., and his son's Annychka saw several major Ukrainian films radically distance themselves from narrative, ideological, and visual clichés. Ivchenko Jr. in Annychka opts for the restrained black-and-white rather than vibrant color film; he also chooses to seek a strong experience of emotional authenticity (as an experiment, he even scheduled the filming of all the scenes in accordance with the chronological order of events). We also see a significant impact of Urusevsky's and Illienko's use of "subjective camera" to render the emotional

${ }^{4}$ On Malick's film in this context, see for example Corrigan 2011: $205 \mathrm{n} 4$. 
experiences of the characters, along with careful attention to ethnographic detail and emphatic anchoring of the film in Ukrainian language and culture. Although - as in Tini zabutykh predkiv-many of the actors cast were non-Ukrainian, the film contains a straightforward articulation of an appeal to Ukrainian identity (ironically, uttered by a character played by a Moldovan actor to a character played by a Russian actor).

Annychka takes us to an ideologically sensitive time period: the summer of 1943, when Eastern Ukrainian guerillas led by Sydir Kovpak, on Stalin's orders, marched towards the Ukrainian section of the Carpathian Mountains, blowing up trains, bridges, oil wells, and refineries. Although here, on Western Ukrainian territory, the Kovpak guerillas suffered heavy losses and were eventually dispersed, this episode provided the only safely pro-Soviet anchor in the history of Western Ukraine during German occupation, where the anti-Nazi resistance movement was dominated by the equally anti-communist Ukrainian Insurgent Army (UPA) and Polish Home Army (Armia Krajowa), who besides fighting the Nazis also fought the Soviets and each other. A significant development in the film's ideological framework, however, is its radical departure from the binary "blackand-white" choice normally available to characters in Soviet war films and an attempt to humanize (and occasionally even portray with a degree of sympathy) those who engage in collaboration with the occupying German forces, turning both Annychka's father (in a powerful performance by Kostiantyn Stepankov) and especially her fiancé into morally complex, evolving characters.

The possibility for the film's humanization of non-Soviet sympathizers was paved by the impact of Wajda's war trilogy, and within the Soviet Union, of the acclaimed Lithuanian film Niekas nenorejo mirti (Nobody Wanted to Die, 1963/65, dir. Vytautas Žalakevičius), whose resonance in Ukraine would be hard to overestimate, and of the film that featured the debut of Annychka's female lead, Liubov' Chernoval-Rumiantseva (b. 1943), the Belarusian feature Al'piiskaia ballada (The Alpine Ballad, 1965). The latter, based on a novella by Vasil' Bykau, centered on the tragic love story between a Belarusian man and an Italian woman, both on the run from the Nazis in the middle of war-torn Europe. This film was unprecedented in the Soviet context in its presentation of World War II experience through prominently focusing on a West European 
protagonist within Western Europe, and in its dramatic deemphasizing of the story's connections to the war as it played out Soviet territories. Al'piiskaia ballada was thus a milestone in "desovietizing" Soviet war narratives, and the neglect of this film in present-day studies of World War II-themed Soviet cinema is hard to fathom given its huge popularity in the Soviet Union at the time of its release, its pioneering setting and themes, and the outstanding screen performances by Chernoval-Rumiantseva and Stanislav Liubshin.

As a result of this complex set of influences by other films that made a strong impact on its creators, Annychka succeeds in pushing the envelope of Soviet World War II cinema through the nearinvisibility of anything identifiably Soviet on screen, as well as by the strongly pacifist outlook originally espoused by the female protagonist (and also by her mother) - a striking accomplishment in the context of when the film was made. ${ }^{5}$ The film's eponymous protagonist can be viewed as a transposition of Marichka from Paradjanov's Tini zabutykh predkiv into the World War II context-a romanticized presentation of a proud, independent young woman who summons courage to defy the "Law of the Father." Her actions - such as nursing a wounded pro-Soviet guerilla fighter-are motivated by her ethical outlook and human emotion (ranging from sympathy to sexual attraction to revulsion at humans killing each other) rather than ideology (anticipating such characters as Anni in Aleksandr Rogozhkin's Kukushka [The Cuckoo, 2002]). Annychka's profoundly individualist self-reliance contrasts with the traditional collectivist emphasis of Soviet ideology, while her use of her own wedding ceremony to organize an escape of a group of POWs offers an example of a woman's bold subversion of patriarchal society's rituals.

In my opinion, a particularly productive clue for reading Annychka is provided by the film's thorough hybridity (in the sense this term is used in postcolonial theory). The space where the film's action takes place is a hybrid of rural tradition and natural beauty with wartime crises of modernity. Aesthetically, it is a hybrid, first, of Ukrainian poetic cinema with its fondness for the ethnographic, the emphasis on an impressionistic presentation of experienced reality, and frequent reliance on unusual camera angles and fluidity, second,

\footnotetext{
${ }^{5}$ In a pivotal scene, Annychka agrees to help the wounded pro-Soviet guerilla fighter she encounters in the forest, but she throws away his gun with the words, Bil'she ne budesh vbyvaty liudei (You won't go around killing people anymore).
} 
of a neorealist-influenced push for emotional and factual authenticity, and, third, of Soviet-style "cinema for the mass viewer" reliant on easily comprehensible, familiar skeleton of the plot, detached and transparently "objective" camerawork, and cliché presentation of the characters. Although it did not receive the international acclaim of Tini zabutykh predkiv or Bilyi ptakh z chornoiu oznakoiu, Annychka attracted a fairly significant domestic audience upon its initial release (25.1 million viewers), and the Soviet authorities judged it worthy of representing the USSR at a film festival in Phnom Penh, Cambodia, in 1969, where it won the jury prize.

Roman thinks of himself as a warrior, not an executioner; his value system and beliefs come to be profoundly shaken by what he witnesses-yet his inability to extricate himself from the atrocities perpetrated by the Nazis in his presence drives him to lose his mind. In a pivotal scene at the center of the film, Roman and Annychka are guests at a ball held at an elegant villa; organized by the occupying authorities, this event includes a presentation of awards to local collaborators (Roman among them) and toadying to visiting highranking German officials. However, Annychka and Roman are the only two guests visibly horrified when, for the sake of amusing the Nazi visitors, the local collaborators devise a macabre entertainment in the form of trying to force captured guerillas to dance barefoot on broken glass before systematically machine-gunning the prisoners. One of the captured guerillas is Ivan, a local youth who had been Roman's longtime rival for Annychka's attention, in a powerful debut performance by another major Ukrainian film actor, Ivan Havryliuk. His defiant dancing of the arkan on broken glass comes to serve as the breakdown of the relatively idyllic lives of Roman and Annychka, and is then echoed in their wedding ceremony that serves as the climax of the film.

During Annychka and Roman's wedding dance a little boy, following the traditional custom, throws on the ground in front of the newlyweds a painted clay bowl that smashes to pieces. The breaking of the bowl, however, now ominously reminds both Annychka and Roman of the broken glass dance and the execution they had witnessed only days before. Annychka appears to be on the verge of fainting and leaves the dancers, and Roman suffers an emotional breakdown, which the film powerfully renders by the sound of the cymbals giving way to the clanking of broken glass, with Roman then 
repeating, in derangement, Ivan's final words. According to the French-Ukrainian scholar Lubomir Hosejko (Hosejko 2005: 216-18), Borys Ivchenko, the film's director, later explained that he borrowed from his father the trope of female heroism as the conduit for portraying the many facets of the war experience in order to use it in part as a vehicle for "smuggling in," albeit through a negative portrayal, the dangerous topic of World War II as lived by ordinary Western Ukrainians. As in Ivanna, the female protagonist evolves from a private person uninterested in social and political issues into someone with a deeper involvement in sociopolitical struggle. However, she remains, in many critics' view, a character decisive in her actions but somewhat schematically drawn (Annychka's choosing the ruggedly handsome but wooden-acting Andrii, a wounded member of Kovpak's guerilla unit, played by the Moldovan actor Grigore Grigoriu, over her two local suitors, is frequently judged as unconvincing). By contrast, the more ambiguous views and actions of her suitors Roman and Ivan, and the emotionally involved performances by the actors portraying them, Ivan Mykolaichuk and Ivan Havryliuk (both of them of Western Ukrainian background themselves, in difference from the Piatigorsk native ChernovalRumiantseva), yielded trouble: on the basis of their performances in this film, both Mykolaichuk and Havryliuk would for years be plagued by accusations of sympathies to "bourgeois" Ukrainian nationalism.

Bilyi ptakh z chornoiu oznakoiu (White Bird with a Black Mark), Yuri Illienko's best-known and most successful film, was conceived in May 1970, around the time of the twenty-fifth anniversary of the end of World War II. The plot, with a fair dose of socialist realist elements, focused on the story of the Dzvonars, a Ukrainian family in Bukovyna, village musicians by their main trade, from the late 1930s to the late 1940s, where one of the brothers, Petro, joins the Soviets, and the other, Orest, the nationalist resistance (this basic plot of brothers joining the opposing ideological sides is at the center of many earlier works, in the Ukrainian case, most notably of Iurii Ianovs'kyi's 1935 novel Vershnyky [The Horsemen], set during the Civil War and adapted into film by Ihor Savchenko in 1939). Bilyi ptakh was the brainchild of Ivan Mykolaichuk, the leading actor of Ukrainian poetic cinema and eventually a noted scriptwriter and director in his own right (this became the first script he co-authored). 
Having just played a humanized, if tragic, member of the nationalist forces who sided with the Germans during the war, he now plays the brother who sides with the Soviets - that he not play the "Banderite" was the condition set by the studio bosses for allowing the film to be made. The role of Orest thus becomes the cinematic debut of the then relatively unknown young theater actor, and later a major film star in his own right, Bohdan Stupka. The two central figures are not only ideological opponents, but also rivals in wooing the beautiful Dana, daughter of the local priest. A third rival, Ivan, a Russian soldier, enters the picture when the local lands are joined to the Soviet Union in 1940. At the wedding of Dana and Ivan, the brothers and their father must play as a hired band. Suddenly, Orest jumps from the band's platform and begins a passionate dance with Dana, a sequence whose stunning cinematography undercuts the legitimacy of Dana's marriage to Ivan, implying instead that Orest is her true soulmate. Suddenly, the outbreak of war with Germany is announced (it is June 1941). Ivan must leave with his brigade immediately and Petro enlists on the spot as well. Dana and Orest escape into the forest on horseback. They become lovers (apparently, Dana was marrying Ivan only out of spite), but after a night together they are captured by a unit that is part of the nationalist insurgent army. Orest is compelled to join them on pain of death, and Dana accompanies him. As the narrative advances three years to 1944, Orest becomes the unit's second-incommand, having adopted its position of collaboration with the Nazis in order to defeat the Soviets.

Toward the end of the film, with the war over, and with both Petro and Ivan having perished at the hands of the nationalist insurgents, Orest returns to the village. Slamming three thousand rubles in paper money down on the platform of a group of musicians, he orders a final dance with Dana, who emerges from the woods. This is another striking sequence cinematographically. After the dance ends, the villagers, led by another brother from the Dzvonar family, Bohdan, pursue Orest along the riverbank and shoot him.

As Herbert Eagle notes in his analysis of the film, "[t]hese are very complicated shots from a technical point of view; making them involved building a circular track around the dancers, with the camera cart spinning around it as the dancers spin around each other. As the couple dances, they slide their arms sensuously along each other's. The camera begins to whirl around them so rapidly that the 
surrounding crowd in the background becomes a blur; then the crowd, as if by magic, seems to disappear entirely" (Eagle 2009). In the second dance sequence, both Orest and Dana are dressed in black; their dance repeats the same movements as the earlier one and once again the camera whirls around them. But the dance, as Eagle notes, "is slower this time; the arms touch with a tenderness and compassion akin to comforting a lover in pain and mourning." When, minutes later, Orest is killed, the death of this ostensibly central villain of the film acquires the dimensions of Christian martyrdom.

The cinematography in these scenes can be seen as the power of the politics of form, fundamental to essay film's challenge to the possibility of access to a single, easily communicated and accepted truth, which fundamentally undercuts the surface socialist realist elements of the film's narrative. The twists and turns of the film's history after completion - at first a near-ban after a disastrous screening at the $24^{\text {th }}$ Congress of the Communist Party of Ukraine in March 1971, then the Gold Medal at the All-Union Film Festival in Leningrad just month later, which ensured Illienko's personal safety during the years of Ukrainian poetic cinema's demise, and finally the ban and withdrawal from international distribution in 1975-testify to the degree with which its politics of form challenged Soviet orthodoxy.

While Khto povernet'sia-doliubyt' is beginning again to receive attention from film scholars, for many years the film was overshadowed, on the one hand, by Leonid Osyka's next project, Kaminnyi khrest (A Stone Cross, 1968), based on two stories from the 1890 s by the Ukrainian modernist author Vasyl' Stefanyk and rightly considered next to Tini zabutykh predkiv and Bilyi ptakh as one of the greatest achievements of Ukrainian poetic cinema, ${ }^{6}$ and on the other, by the traumatic history of the film's production. This complicated story begins in 1963, when Perevirte vashi hodynnyky (Check Your Watches), a film script co-authored by Lina Kostenko, one of Ukraine's greatest women poets and a leading author of her generation, and Arkadii Dobrovol's'kyi, at the time a recent returnee from Kolyma who had spent twenty-two years there first as a GULAG inmate and later as an exile, won a Ukraine-wide competition and was published in the literary monthly Dnipro. The script is an essayistic

${ }^{6}$ For more on this film, see Chernetsky 2008. 
meditation on the lives and writings of three young Ukrainian poets who perished on the frontlines of World War II and, in a symbolic gesture, were admitted posthumously into the Ukrainian Writers' Union in 1962. This collaboration of a woman poet who herself would soon endure many years of persecution for her dissident stance and a screenwriter whose professional career had been interrupted for nearly a quarter century was part and parcel of the Thaw-era radical rethinking of the World War II experience in the Soviet Union and one of the pinnacles of this revisionist trend in Ukraine. An abstract, symbolist-influenced text whose characters bear names like Woman Who Bore Poetry in Her Bosom, Battalion Commander Who Still Did Not Die for His Motherland, or Person in Favor of Whatever Power Is in Power, it radically dispensed with the trappings of socialist realist aesthetics. In true poetic essay film fashion, it blended documentary material with surreal, dreamlike episodes in a subjective narrative open to diverging interpretations.

The film was assigned to the recent VGIK graduate, a promising young director named Vasyl' Illiashenko. Full of youthful enthusiasm and fervor, and buoyed by the considerably freer atmosphere of the Moscow intellectual circles of his student years, he dove headlong into the project, casting the then rising star of Ukrainian poetic cinema, Ivan Mykolaichuk, in the synthetic role of the Poet. The filming was about three quarters complete when an order came to halt production. Despite the intercession on Illiashenko's behalf by his mentor, the prominent director and VGIK professor Sergei Gerasimov, the Party authorities in Ukraine ordered the project suspended; the script and the film were accused of "tarnishing Soviet reality," "falsifying historical facts," and of "an attraction to creating ciphers" (Illiashenko 2004). Dealing with the controversial and sensitive issues of Stalinism and the suffering brought by the war onto the Ukrainian lands, the project caused extreme displeasure of the Ukrainian Communist Party leadership. In a rare gesture for its time (as opposed to the 1930s), the already shot footage was ordered burned, and only a few fragments have survived thanks to the courage of one of the editors. Illiashenko himself was officially temporarily disqualified from directing films; he eventually completed his first project as a director, a tedious and insincere socialist realist story set in the Donbas coalmines, in 1971. None of 
his completed films have risen to the level of ambition and innovation of his first unfinished work.

In an unusual twist, the project was then reassigned for reworking and completion to another promising VGIK graduate, Leonid Osyka, who approached it as a challenge with hopes to save the studio's reputation. Osyka's task was to complete the film without additional funding and with a radically smaller crew. Given this challenge, he was granted complete freedom in reworking the script and in organizing the production process. The new script preserves some elements of the original, but also makes rather drastic changes. In a gesture that can be seen as an attempt to placate the censors, the story now follows the lives and writings of two wartime poets: one Ukrainianophone, Volodymyr Bulaienko (a somewhat controversial figure within the official Soviet narrative, since he was taken captive by the Nazis in the fall of 1941 yet escaped, returned to his native village that was by then deep within the Nazi-occupied territory, and only rejoined the Soviet army in 1944, perishing shortly afterwards), and one Russophone, Semion Gudzenko, likewise a native of Ukraine but safely canonized as a wartime Russian-language poet who, although gravely wounded in 1942, was never in Nazi-occupied territory and lived to see the end of the war, dying of old wounds in 1953. The new title for the film is taken from a line from one of Gudzenko's best-known poems, "Moe pokolenie" ("My Generation," 1945). Given the radical changes to the script, Lina Kostenko asked for her name to be removed from the credits. With Mykolaichuk unavailable, as he had begun filming another project, the role of the Poet was given to the ruggedly handsome actor Borys Khmel'nyts'kyi (a.k.a. Boris Khmel'nitskii) who, although of Ukrainian background, was based at the famed Taganka Theater in Moscow.

The resulting film strikes by the similarity of its aesthetics to Paradjanov's unfinished project and is very different from Osyka's other work. A slow-paced series of painterly tableaux vivants (although not in color, like Kÿ̈vs'ki fresky, but in rich, contrasting black-and-white), it focuses on the Poet, who is meant to symbolize the fate of the thousands of young men who left for the front and never came back, in his encounter with other, unnamed characters. Linguistically, the film is a bilingual hybrid, switching regularly between Ukrainian and Russian without any subtitles or voiceover translation. The only non-diegetic voiceover is comprised by recorded 
documentary recollections about their sons by mothers of fallen soldiers and by Borys Khmel'nyts'kyi's reciting of texts by the two poets (again, switching back and forth between the Ukrainian and the Russian).

The plot is simple: a panoramic pan of modern-day Kyiv and the opening credits accompanied by the quiet yet persistent staccato sound of a name being carved on a memorial headstone are followed by a series of poetic vignettes: in an abstractly rendered traditional Ukrainian village home a mother pours milk and slices off a hunk of bread while the Poet-soldier gets up from his bed, dresses in combat fatigues, and, as mother looks back, leaves the house to join dozens of other similar-looking young men walking away from the camera. A quick montage of documentary war footage is presented in complete silence, which is then broken by the reciting of a poem. We next move to a poetically abstracted scene of Soviet soldiers in the trenches near a riverbank, defending it yet receiving orders to retreat. One of them refuses to retreat and continues shooting. The Poet stays with him, and when this other soldier is wounded, takes him on a raft across the river; there he and another soldier are attacked by a German warplane. The Poet, although wounded, is the sole survivor.

He makes it to a house where a woman, in a scene strikingly reminiscent of Tini zabutykh predkiv, bathes him and helps him dress. The only men's civilian clothing she can find is her husband's wedding suit. When a German soldier walks in to confront them, she pleads with him that this is her husband and thus saves the Poet. In the episode that follows, the Poet, in plain civilian clothes, walks through a static, oneiric wartime market in an occupied small town where he meets a young woman. The two of them take a silent but emotionfilled walk together, reaching an empty open-air theater. Following a sudden transition, in the scene that follows, daringly for the Soviet context of its time alluding to the Holocaust, the Poet is caught in the midst of a group of Roma that have just been rounded by the Nazis and are about to be executed; several Roma shout to their captors that he is not a gypsy, and the Nazi soldiers push the Poet away. In one of the final episodes, the Poet confronts another poet who hides out in a beautiful neo-Gothic building with smashed windows and who is fearful and broken down by the war; rejecting his stance, the protagonist eventually joins a guerrilla unit. He recites Gudzenko's "My Generation" in front of the fellow guerrillas as they wait for a 
passing Nazi train to explode on a mine they had set. The men are told that this is a train carrying prisoners rather than munitions as they had originally thought. The Poet runs to the train to stop it, engages the Nazis, and then tries to open a train car's door to liberate the prisoners, only to have the rich Ukrainian black soil-the Nazis' symbolic loot-pour out from it onto him, before the epilogue returns us to a modern-day view of a soldiers' cemetery.

The film bears several crucial hallmarks of poetic cinema: the dialogue is reduced to the absolute minimum; visual expressive means are dominant over the rudimentary narration; many of the scenes have oneiric quality; in the tradition of Eisensteinian tipazh, the actors, whether professional or non-professional, are visually striking; the acting is improvisational; the music solemn and powerfully emotional. Like Osyka's masterpiece Kaminnyi khrest, filmed immediately afterwards, the production was completed on a shoestring budget (Hosejko 2005: 203-04). At the same time, in its incorporation of disparate strands of the documentary, the dreamlike, and quotations both visual and textual, Khto povernet'sia also fully merits being categorizes as an essay film.

While fascinating and in many respects striking viewed from the vantage point of today, the film's further fate remained unlucky. The trauma of its production history resulted in critics' fear of discussing the finished product; the few who did as a rule deemed it less successful than other poetic cinema works. Khto povernet'sia, not unlike Annychka, is ultimately an attempt at a compromise between an original vision of a poetic essay film and the demands of Soviet ideology and aesthetic censorship. The fact that in the finished film's voiceover and dialogue the Russian language predominates over Ukrainian (also likely an attempt to placate the censors) turned off many members of the Ukrainian intelligentsia. Then, in a startling development, for a few years beginning in 1968, Bulaienko, the Ukrainian-language poet whose work was featured in the film, became a proscribed figure as new questions arose regarding his activities while on the Nazi-occupied territory; all the official memorials dedicated to him were removed, and he became unmentionable. This trend only reversed in 1973, when a volume of Bulaienko's collected poetry in Russian translation was published in Moscow and he was fully exonerated of all the accusations. Still, for Osyka the project was 
a qualified success, and paved the way for the triumph of his next and greatest work, Kaminnyi khrest.

After the suppression of Ukrainian poetic cinema in 1972-73, the most notable World War II-themed films made in Ukraine were the two by Leonid Bykov, the 1974 V boi idut odni "stariki" (Only the "Old" Go into Battle) and the 1976 Aty-baty shli soldaty (OneTwo the Soldiers Were Going). With their humanist message, generic Russian-language production, nonspecific setting, and considerable commercial success, they did not stray from the mainstream Great Patriotic War discourse as it consolidated in Soviet cinema by then.

Fast-forwarding to the independence era, amidst the economic and technical crisis that severely undercut the Ukrainian film industry during the last twenty years, the most notable accomplishment in engaging with the memory of World War II has been undertaken by Serhii Bukovs'kyi (b. 1960), who has emerged as contemporary Ukraine's leading innovative documentary filmmaker. Two of his films are central in this respect: the made-for-television Viina: Ukraïns'kyi rakhunok (War: Ukrainian Account, 2003) and the Stephen Spielberg-produced film on the Holocaust in Ukraine, Nazvy svoie im 'ia (Spell Your Name, 2006).

Both these films are structured as reflexive, investigative essays. Both emerged out a search to rethink the topic anew, avoiding facile ideological clichés. Somber, melancholy, measured, amassing enormous archival material and many interviews with rank-and-file veterans and survivors, as well as with representatives of postwar generations living in different regions of Ukraine and in Germany, War: Ukrainian Account seeks to present respectfully as many ideological viewpoints as possible, and to avoid dehumanizing any of the sides of the conflict. At the same time, it looks unflinchingly at the horrifying losses of human life (about 14 million dead on the Ukrainian territory alone during the war years, according to the film), the destructions of cities, towns, and villages, and all the aspects of war in its savagery, human bravery, and even in its routine. It is, fundamentally, also a meta-level reflection on film as documentation and on the (im)possibility to access and comprehend a truth that lies behind the uncovered facts and testimonies. The essayistic element goes even further in Spell Your Name, as the mosaic of accounts by the survivors and the Gentiles who aided them, along with various forms of archival material, is intercut, on the one hand, with the 
filmmaker's own quest for a unifying vision of a film about something that is ultimately unrepresentable in the magnitude of its horror, and on the other, with interviews with the young film school students who help decipher the recorded testimonies of the survivors. What Corrigan sees as central to the essay film endeavor, namely "stretch[ing] and balanc[ing] . . . between [a] representation of the self (in language and image) and an experimental world encountered and acquired through the discourse of thinking out loud" [15], aptly describes the momentum propelling Bukovs'kyi's essayistic films (besides the two World War II-themed projects, notably including his intellectually fearless and emotionally powerful attempt at tackling the Holodomor, Ukraine's Stalin-era terror famine, in Zhyvi [The Living, 2008]). Essay film "invites different forms of expression, and different dimensions and ways of engagement with the real-ways that are more contingent, marginal, autobiographical, even private" (Rascaroli 2009: 190). The epithets given to essay film in theoretical writingprotean, digressive, contradictory, political, and crucially "in between categories"-all seem befitting for Bukovs'kyi's project. I would argue that in his films, the essayistic intertwines with the poetic to produce a complex elegiac journey. Critics have seen this type of elegiac motif as central to the essay films of Aleksandr Sokurov. For all the aesthetic and thematic difference between the Russian director and Bukovs'kyi, their careful, respectful engagement with the poetic cinema tradition in their own essayistic projects signals, in my opinion, one of the most powerful and productive approaches to the ever-challenging topic of human memory in its encounter with the traumatic and the (almost) unrepresentable, and points to a productive path of further engagement with these challenges.

\section{References}

Alter, Nora M. 1996. 'The Political Im/perceptible in the Essay Film: Farocki's Images of the World and the Inscription of War,' New German Critique, no. 68 (1996): 165-92.

2002. Projecting History: German Nonfiction Cinema, 1967-2000. Ann Arbor: University of Michigan Press.

Chernetsky, Vitaly. 2008. 'Visual Language and Identity Performance in Leonid Osyka's A Stone Cross: The Roots and the Uprooting,' Studies in Russian and Soviet Cinema, vol. 2, no. 3 (2008): 269-80.

Corrigan, Timothy. 2011. The Essay Film: From Montaigne, after Marker. New York: Oxford University Press. 
Eagle, Herbert. 'How Poetic Structure Counters Socialist Realist Narrative in Illienko's White Bird with a Black Spot,' http://www.kinokultura.com/specials/9/eagle.shtml

Hosejko, Lubomir. 2001. Histoire du cinéma ukrainien, 1896-1995. Dié: Éditions à Dié.

2005. Istoriia ukraïns'koho kinematohrafa. Kyiv: Kino-kolo [Ukrainian translation of Hosejko 2001].

Illiashenko, Vasyl' [Il'iashenko, Vasilii]. 2004. 'Vzryvaia sotsrealizm,' 2000, no. 25 (225), 18-24 June 2004: C1, C7, http://2000.net.ua/is/71/225-c1.pdf, http://2000.net.ua/is/71/225-c1.pdf.

Oleksandr Dovzhenko: Tvorcha spadshchyna. Anotovanyi kataloh. Kyiv: n.p., 2007.

Papazian, Elizabeth. 2003. 'Offscreen Dreams and Collective Synthesis in Dovzhenko's Earth,' Russian Review, vol. 62, no. 3 (2003): 411-28.

Rascaroli, Laura. 2009. The Personal Camera: Subjective Cinema and the Essay Film. London: Wallflower Press.

Steffen, James M. 'Kyiv Frescoes: Sergei Paradjanov's Unrealized Film Project,' http://www.kinokultura.com/specials/9/steffen.shtml

Williams, Bruce. 1994. 'A Mirror of the Cinema: Poetic Discourse and Autotelic Aesthetics in Dovzhenko's Earth,' Journal of Ukrainian Studies, vol. 19, no. 1 (1994): 67-83.

Woll, Josephine. 2000. Real Images: Soviet Cinema and the Thaw. London: I.B. Tauris.

Youngblood, Denise. 2007. Russian War Films: On the Cinema Front, 1914-2005. Lawrence: University Press of Kansas. 